\title{
Ефективність своєчасної та якісної догоспітальної електричної дефібриляції при раптовій зупинці кровообігу
}

\author{
R. M. LIAKHOVYCH, M. YA. DZUS, I. A. PROTSIUK \\ SHEI "Ternopil State Medical University by I. Ya. Horbachevsky"
}

EFFECTIVENESS OF TIMELY AND HIGH-QUALITY PREHOSPITAL DEFIBRILLATION DURING THE
SUDDEN CARDIAC ARREST

У статті висвітлено основні види зупинки кровообігу при ЕКГ-моніторуванні потерпілих, які перебувають у стані клінічної смерті. Доведено ефективність свосчасної та якісної догоспітальної дефібриляції на тлі підтвердженої фібриляції шлуночків та шлуночкової тахікардії без пульсу.

The article highlights the main types of circulatory arrest during ECG monitoring in victims in a state of clinical death. Proved the effectiveness of timely and high-quality prehospital defibrillation on the background of confirmed ventricular fibrillation and ventricular tachycardia without a pulse.

Постановка проблеми і аналіз останніх досліджень та публікацій. 3 року в рік статистика свідчить про високий рівень догоспітальної летальності потерпілих, яким проводили реанімаційні заходи. Встановлено, що із десяти таких постраждалих виживають заледве двоє.

Водночас, на кінцевий результат серцево-легеневої та мозкової реанімації (СЛМР) впливає ціла низка визначальних факторів: часові межі діяльності бригади екстреної (швидкої) медичної допомоги (Е(Ш)МД), характер і тяжкість захворювання (травми), час настання клінічної смерті, наявність (відсутність) домедичної допомоги, професійна підготовка медиків та їх оснащення тощо. Варто також вказати на ряд окремих етично-юридичних моментів з даної проблематики. Рішення про початок проведення реанімаційних заходів $є$ досить складною темою як для лікаря, так і для пацієнтів та їх рідних. Серед чинників, які впливають на прийняття таких дій, $є$ особисті фактори, національні та локальні традиції, юридичні, етичні, релігійні, суспільні та економічні аспекти. Саме тому настільки важливим $\epsilon$ вміння працівниками служби Е(Ш)МД при наданні медичних послуг даній категорії хворих дотримуватися основних принципів у прийнятті рішення щодо показань, протипоказань, тривалості та якості серцево-легеневої та мозкової реанімації (СЛМР) на основі сучасних алгоритмів $[1,4]$.
Мета роботи: довести ефективність своєчасної та якісної догоспітальної електричної дефібриляції при раптовій зупинці кровообігу.

Матеріали і методи. У новітніх рекомендаціях Європейської ради ресусцитації (2012р.), клінічних протоколах медицини невідкладних станів (наказ № 34 MO3 України від 15. 01.2014 р.) чітко окреслено головний діагностичний крок медиківреаніматорів на тлі розпочатої СЛМР - ЕКГ-діагностика виду раптової зупинки кровообігу (РЗК).

У дорослих найчастішим порушенням ритму під час РЗК є фібриляція шлуночків (ФШ) і шлуночкова тахікардія без пульсу (ШТ), а саме близько $80 \%$. ФШ характеризується хаотичними, асинхронними скороченнями кардіоміоцитів 3 наявністю на ЕКГ нерегульованих, із частотою 400-600/хв низько -, середньо-, або високоамплітудних коливань (рис. 1).

ШТ без пульсу характеризується деполяризацією кардіоміоцитів шлуночків із високою частотою. На ЕКГ відсутні зубці Р і наявні широкі GRSкомплекси (рис. 2).

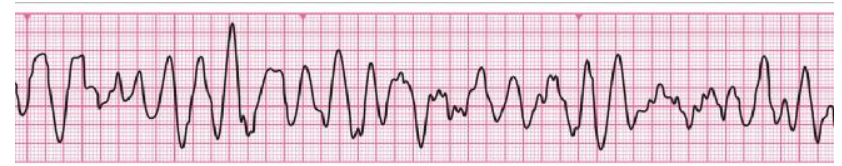

Рис. 1. Крупнохвильова фібриляція шлуночків. 


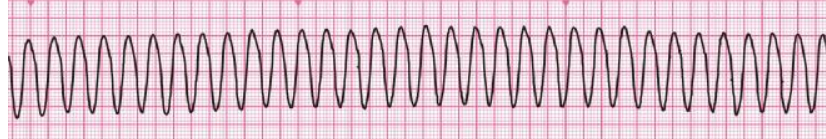

Рис. 2. Шлуночкова тахікардія без пульсу.

Принцип дефібриляції полягає в деполяризації критичної маси міокарда, що призводить до відновлення синусового ритму природним водієм ритму (через те, шо клітини пейсмекера синусового вузла $€$ першими клітинами міокарда, здатними деполяризуватися спонтанно). Рівень енергії першого розряду є компромісом між його ефективністю та впливом, що ушкоджує міокард. Водночас раннє виконання дефібриляції необхідне ще й через те, що в перші хвилини РЗК ще не спостерігається вираженої ішемії міокарда та накопичення в ньому молочної кислоти (кінцевого продукту анаеробного гліколізу). Все це вимагає негайного якнайшвидшого проведення бригадою Е(Ш)МД дефібриляції. Оцінка ритму не повинна перевищувати 8-10 с. Після підтвердження за допомогою класичних або самоприклеювальних електродів, ложок дефібрилятора ритмів ФШ або ШТ (маніпуляцію може виконувати один із фельдшерів) негайно приступають до реалізації частини клінічного протоколу РЗК “ритм до дефібриляції. При цьому виконується дефібриляція № 1 енергією 150-200 Дж для двофазового дефібрилятора (360 Дж для однофазового) в максимально короткий термін (не більше 5-7 с).

Відразу після дефібриляції, без повторної оцінки ритму чи пошуку пульсу, слід продовжити реанімаційні заходи (30 натискань: 2 вдування повітря) впродовж 2 хв, а потім зробити коротку перерву, щоб оцінити ритм на моніторі. Якщо й надалі утримується ФШ/ШТ, проводять дефібриляцію № 2, при цьому енергію у двофазовому дефібриляторі збільшують на 50 Дж (360 Дж однофазовим), виконують наступний двохвилинний етап СЛМР, після якого із наступною мінімальною перервою на реанімаційні заходи повторно оцінюють ритм. За наявності повторного підтвердження ФШ/ШТ виконують дефібриляцію № 3, вкотре збільшуючи енергію двофазовим дефібрилятором на 50 Дж (360 Дж однофазовим) на тлі компресії грудної клітки та штучної вентиляції легень.

У цей час вводиться завчасно підготовлений фельдшером (медичною сестрою) $0,1 \%$ розчин адреналіну у дозі 1 мл, розведений у 10 мл $0,9 \%$ $\mathrm{NaCl}$, а також розчин аміодарону в дозі 300 мг, розведений у $5 \%$ розчині глюкози внутрішньовенно болюсно на тлі продовження СЛМР (2 хв). Подальші дії: оцінка ритму, при повторному підтвердженні ФШ/ШТ - дефібриляція № 4 з аналогічним збільшенням енергії для двофазового дефібриля- тора на 50 Дж та сталою енергією для однофазового (360 Дж).

Результати досліджень та їх обговорення. Алгоритм функціональних обов'язків бригади Е(Ш)МД та особливості виконання протоколу раптової зупинки кровообігу.

- Під час СЛМР проводиться безперервна компресія грудної клітки (фельдшер, водій) асинхронно $з$ вентиляцією.

- Фельдшер (медична сестра) забезпечує катетеризацію периферичної вени.

- Лікар за участю медпрацівника проводить інтубацію трахеї та ШВЛ із середньою частотою 10 за 1 хв та дихальним об'ємом 400-600 мл (67 мл/кг) $\mathrm{FiO}_{2}$ 1,0 або використовує альтернативні методи ШВЛ.

Перерви між натисканнями на грудну клітку та виконанням дефібриляції не повинні перевищити 57 с. Більш тривалі паузи зменшують шанси на виконання ефективної дефібриляції, яка здатна повернути спонтанний кровообіг.

Безпосередньо після дефібриляції, без повторної оцінки ритму чи перевірки пульсу, необхідно продовжити реанімаційні заходи, починаючи з натискання на грудну клітку. У випадку, якщо дефібриляція буде ефективною та відновить перфузійний ритм, дуже рідко можна визначити пульс безпосередньо після самої дефібриляції. Запізнення, спричинене оцінкою пульсу, в ситуації, коли перфузійний ритм не був відновлений, негативно вплине на міокард.

Варто зазначити, що при відновленні перфузійного ритму компресія грудної клітки не збільшує ризику повернення ФШ. У випадку розвитку асистолії безпосередньо після дефібриляції компресія грудної клітки може бути ефективною, оскільки сприятиме появі ФШ - прогностично більш сприятливого виду зупинки кровообігу порівняно з асистолією.

Перша доза адреналіну вводиться відразу після підтвердження ритму (ФШ/ШТ) безпосередньо після виконання третьої дефібриляції (послідовність: дефібриляція >ліки $>$ СЛМР $>$ оцінка ритму). Наступні дози адреналіну вводяться безпосередньо перед кожною другою дефібриляцією так довго, доки буде утримуватися ФШ/ШТ. Адреналін повинен бути підготовлений фельдшером для введення завчасно, щоб забезпечити якнайкоротший часовий проміжок між перериванням компресій грудної клітки та виконанням дефібриляції. Препарат, введений безпосередньо після дефібриляції, буде розповсюджений в організмі завдяки реанімаційним заходам, які розпочнуться відразу після дефібриляції. Якщо ж адреналін завчасно не буде підготовлений, то його слід ввести після виконання дефібриляції. Не мож- 
на запізнюватися з дефібриляцією в очікуванні на введення адреналіну.

Виникнення асистолії на тлі виконання частини протоколу “ритму до дефібриляції” зобов'язує бригаду, продовжуючи СЛМР, перейти до іншої частини протоколу - “ритм не до дефібриляції” $[10,11]$.

Моніторування відновленого ритму після двохвилинного проведення СЛМР не є підставою до переривання натискань на грудну клітку з метою оцінки пульсу. Винятком є поява зовнішніх ознак ефективної реанімації, які будуть вказувати на відновлення спонтанного кровообігу. В такому випадку реанімаційні заходи припиняються і лікар бригади повертається до 8-10-секундного моніторингу дихання та кровообігу.

У випадку констатації на ЕКГ впорядкованого ритму, але із сумнівами щодо наявності пульсу СЛМР продовжують. Якщо ритм зміниться на асистолію або безпульсову електричну активність, треба діяти згідно з алгоритмом для ритмів “не до дефібриляції” [2].

Коли існують будь-які сумніви щодо того, чи ритм відповідає асистолії, а чи дрібнохвильовій фібриляції, рятівникам варто працювати за протоколом “ритм не до дефібриляції”, а саме продовжувати компресію грудної клітки і проводити ШВЛ. Існує мала ймовірність того, щоб спроба сеансу дефібриляції при підозрі на низькоамплітудну ФШ, яку важко відрізнити від асистолії, могла б відновити ритм 3 мінімально адекватною перфузією. Через це продовження якісної СЛМР здатне покращити амплітуду та частоту ФШ, тим самим підвищити шанс ефективної дефібриляції та повернення спонтанного кровообігу. Важливо перевірити положення та контакт електродів, коли спостерігається ФШ/ШТ, які є стійкими до сеансів дефібриляції.

Провідне місце належить формі електричного імпульсу - для виконання успішної дефібриляції біполярним імпульсом (порівняно з монополярним) потрібно приблизно в 2 рази менше енергії. Згідно 3 останніми даними успіх дефібриляції імпульсом біполярної синусоїдальної форми $<115$ Дж становить $92 \%$. Водночас сумарна ефективність імпульсу монополярної форми залежно від виду ФШ становить при енергії розряду 200 Дж 60-90 \%, або в середньому близько $70 \%$.

Іншим важливим фактором, що впливає на ефективність дефібриляції, $\epsilon$ правильне розташування електродів на грудній клітці. Оскільки тільки $4 \%$ трансторакального струму проходить через серце, а $96 \%$ - через інші структури грудної клітки, важливим є їхнє адекватне розташування. Так, при верхівково-передньому розташуванні один електрод розміщується з правого краю груднини під клю- чицею, другий - латеральніше лівого соска по середньо-пахвинній лінії.

При передньо-задньому розташуванні один електрод встановлюється медіальніше лівого соска, інший - під лівою лопаткою (рис. 3,4 ).

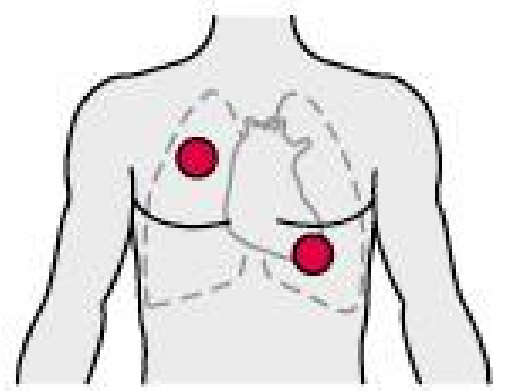

Рис. 3. Верхівково-переднє розташування електродів.

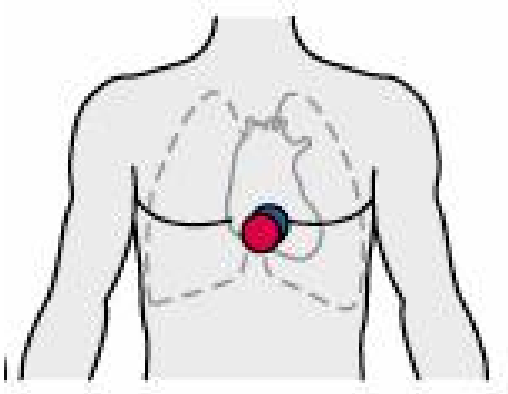

Рис. 4. Передньо-заднє розташування електродів.

Якщо в постраждалого $є$ імплантований кардіостимулятор, електроди дефібрилятора повинні розташовуватися від нього на відстані близько 6$10 \mathrm{~cm}$.

Третім фактором є опір грудної клітки, або трансторакальний опір. Явище трансторакального імпедансу (опору) має важливе клінічне значення, тому що саме воно пояснює різницю енергії струму між тим, що набирається на шкалі апарата, і тим, що проходить через тіло постраждалого. Якщо при реанімації мають місце фактори, які істотно підвищують трансторакальний імпеданс, то цілком ймовірно, що при встановленні на шкалі дефібрилятора енергії 360 Дж ії реальне значення може скласти на міокарді в найкращому разі $10 \%$ (тобто 30-40 Дж) $[7,8]$.

Трансторакальний опір залежить від маси тіла i, в середньому, становить 70-80 Ом у дорослої людини. Для зменшення трансторакального опору дефібриляцію необхідно проводити у фазу видиху, тому що трансторакальний опір у цих умовах знижується на 16 \%. Крім того, при дефібриляції за допомогою “ложок” оптимальним вважають зусилля, що прикладається на останні, яке дорівнює 8 кг для дорослих і 5 кг для дітей у віці 1-8 років. Водночас $84 \%$ зниження трансторакального опору 
здійснюється за рахунок забезпечення щільного контакту між шкірою та електродами за рахунок застосування струмопровідних гелів або розчинів.

Висновки. Успіх дефібриляції можна прогнозувати з різним ступенем надійності згідно з видом порушень ритму серця. При ресстрації на ЕКГ ФШ/ШТ ефективність дефібриляції залежить від ії своєчасного та технічно правильного виконання, в

\section{СПИСОК ЛІТЕРАТУРИ}

1. Гродецький В. К. Екстрена медична допомога. Вибрані аспекти : практичний посібник / В. К. Гродецький, А. А. Гудима, Д. Е. Доморацький. - К., 2014. - С. 42-51.

2. Усенко Л. В. Серцево-легенева і церебральна реанімація: нові рекомендації Європейської Ради з реанімації 2005 р. і невирішені проблеми реаніматології на Україні / Л. В. Усенко, Л. А. Мальцева, А. В. Царьов // Медицина невідкладних станів. - 2006. - № 4. - С. 17-22.

3. Усенко Л. В. Серцево-легенева і церебральна реанімація : практичний посібник / Л. В. Усенко, А. В. Царьов. -2-ге вид., випр. і доп. - Дніпропетровськ, 2008. - 47 с.

4. Неговський В. А. Післяреанімаційна хвороба - нова нозологічна одиниця. Реальність і значення / В. А. Неговський, А. М. Гурвич // Експериментальні, клінічні та організаційні проблеми реаніматології. - М. : НІІОР, 2006. - С. 3-10.

5. Усенко Л. В. Післяреанімаційна хвороба: далеко не реалізований потенціал / Л. В. Усенко, А. В. Царьов, В. В. Яровенко // Медицина невідкладних станів. - 2008. - № 4. - С. 9-16. 6. Усенко Л. В. Штучна гіпотермія в сучасній реаніматології / основі чого є дотримання базових сучасних алгоритмів. На сьогодні проводяться перспективні дослідження, метою яких є визначення оптимального часу дефібрилюючого імпульсу та оптимального часу нанесення розряду. Вищенаведене дасть змогу уникнути впливу малоефективних розрядів високої енергії і, тим самим, мінімізувати пошкодження міокарда та, як наслідок, зменшити рівень догоспітальної летальності потерпілим із РЗК.

Л. В. Усенко, А. В. Царьов // Загальна реаніматологія. - 2009. - № 1. - C. 21-23.

7. Nolan J. P. The (new) European 2010 Resuscitation Guidelines. The latest evidence-based treatment recommendations. $-1 \mathrm{st}$ Edition. - Elsevier, 2010. - P. 79-87.

8. European Resuscitation Council Guidelines for Resuscitation 2010. Section 4. Adult advanced life support / C. D. Deakin, J. P. Nolan, J. Soar [et al.] // Resuscitation. - 2012. - Vol. 81. - P. 1305-1352.

9. Adult basic life support and use of automated external defibrillators / A. J. Handley, R. Koster, K. Monsieurs [et al.] // European Resuscitation Council Guidelines for Resuscitation. 2012 / J.P. Nolan, P. Baskett (Ed.). - Elsevier, 2009. - P. 7-23. 10. Gurevich A pioneer of defibrillation / L. V. Ussenko, A. V. Tsarev, Y. A. Leschenko L. Naum // Resuscitation Greats / P. Baskett, T. Baskett (Eds.). - Clinical Press, 2007. - P. 200-202.

11. Outcome following admission to UK intensive care units after cardiac arrest: a secondary analysis of the ICNARC Care Mix Programme Database / J. P. Nolan, S. R. Laver, C. A. Welch [et al.] // Anaesthesia. -2012. - Vol. 62. - P. 1207-1216.

Отримано 27.01.15 